CORRESPONDENCE

\section{Author's response: What characteristics of primary care and patients are associated with early death in patients with lung cancer in the UK?}

We thank Rogers et $a l^{1}$ for their comments on our recent article. ${ }^{2}$ Although it is possible that there may be some underreporting of chest X-ray (CXR) requests in The Health Improvement Network primary care data set, it is highly unlikely that the associations that we identified in our paper ${ }^{2}$ are influenced by this because the practice of underreporting of CXRs is unlikely to be related to deaths from early cancer. For this reason, if anything, our findings may even underestimate the true associations. We know that almost $40 \%$ of patients with lung cancer are diagnosed via an emergency route, ${ }^{3}$ so we were expecting that the patients who died early would be less likely to have undergone primary care CXR. Our CXR rates are corrected for background lung cancer incidence in our multivariable analysis and there was no association between high background lung cancer rates and higher CXR rates. The focus of this paper was on early death from lung cancer, hence a comment on long-term survival and the factors that influence this are outside the remit of the paper.

Although we agree with Rogers et al that reliance on primary care to identify lung cancer with no additional tools to identify those at greatest risk is unlikely to be successful, we do not feel that a more liberal CXR requesting policy is likely to be the

best answer. Iyen-Omofoman et $a l^{4}$ derived and validated a risk assessment tool, which had greater discriminatory ability compared with current National Institute of Health and Care Excellence (NICE) guidelines. The use of a predictive score meant that for each case of lung cancer detected 119 CXRs would need to be performed, when compared with 421 CXRs per case using current NICE guidelines. Others have produced similar tools. ${ }^{5}$ As suggested in our paper, we believe that the most promising approach is to provide primary care colleagues with validated tools that allow better targeting of investigations.

Emma L O'Dowd, ${ }^{1}$ Tricia M McKeever, ${ }^{1}$

David R Baldwin, ${ }^{2}$ Sadia Anwar, ${ }^{2}$

Helen A Powell,' ${ }^{1}$ Jack E Gibson,'

Barbara Iyen-Omofoman, ${ }^{2}$ Richard B Hubbard ${ }^{1}$

${ }^{1}$ Division of Public Health and Epidemiology, University of Nottingham, Nottingham, UK

${ }^{2}$ Department of Respiratory Medicine, David Evans

Building, Nottingham City Hospital, Nottingham, UK

Correspondence to Dr Emma O'Dowd, Division of Public Health and Epidemiology, University of Nottingham, Room C100, Clinical Sciences Building, Nottingham City Campus, Hucknall Road, Nottingham NG5 1PB, UK; emma.o'dowd@nottingham.ac.uk

Contributors ELO'D drafted the response and all authors were involved in reviewing the response prior to submission.

Competing interests None.

Provenance and peer review Not commissioned; internally peer reviewed.

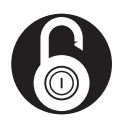

\section{OPEN ACCESS}

pen Access This is an Open Access article distributed in accordance with the Creative Commons
Attribution Non Commercial (CC BY-NC 4.0) license, which permits others to distribute, remix, adapt, build upon this work non-commercially, and license their derivative works on different terms, provided the original work is properly cited and the use is noncommercial. See: http://creativecommons.org/licenses/ by-nc/4.0/

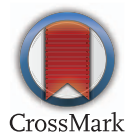

To cite O'Dowd EL, McKeever TM, Baldwin D R, et al. Thorax 2015;70:185.

Accepted 1 December 2014

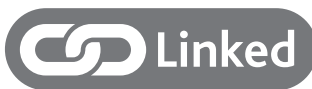

http://dx.doi.org/10.1136/thoraxjnl-2014-205692

http://dx.doi.org/10.1136/thoraxjnl-2014-206514

Thorax 2015;70:185

doi:10.1136/thoraxinl-2014-206638

\section{REFERENCES}

1 Rogers TK, Hamilton W, Tod A, et al. Response to: What characteristics of primary care and patients are associated with early death in patients with lung cancer in the UK? Thorax 2015:70:184.

2 O'Dowd EL, McKeever TM, Baldwin DR, et al. What characteristics of primary care and patients are associated with early death in patients with lung cancer in the UK? Thorax 2015;70:161-8.

3 Elliss-Brookes L, McPhail S, Ives A, et al. Routes to diagnosis for cancer-determining the patient journey using multiple routine data sets. $\mathrm{Br} J$ Cancer 2012;107:1220-6.

4 Iyen-Omofoman B, Tata LJ, Baldwin DR, et al. Using socio-demographic and early clinical features in general practice to identify people with lung cancer earlier. Thorax 2013;68:451-9.

5 Hamilton W, Peters TJ, Round A, et al. What are the clinical features of lung cancer before the diagnosis is made? A population based case-control study. Thorax 2005:60:1059-65.

6 Hippisley-Cox J, Coupand C. Identifying patients with suspected lung cancer in primary care: derivation and validation of an algorithm. Br J Gen Pract 2011;61: e715-23. 